\title{
Evaluation of a rapid detection method of Salmonella in comparison with the culture method and microbiological quality in fish from the Brazilian Amazon
}

\author{
Paula Hellayne Costa dos SANTOS ${ }^{1 *}$, Hamilton M. FIGUEIREDO ${ }^{1 *}$, Luiza Helena Meller da SILVA ${ }^{1 \# *}$ (D), \\ Rafaela Santos Oliveira da SILVA ${ }^{1 \#}$, Gabrielle Virginia Ferreira CARDOSO ${ }^{2 *}$, Carina Martins MORAES ${ }^{2 *}$, \\ Antonio Manoel da Cruz RODRIGUES ${ }^{1 *}$
}

\begin{abstract}
Microbiological safety of fish is a concern of consumers, industries and regulatory agencies worldwide. Among the pathogenic microorganisms, Salmonella spp. is one of the main agents of foodborne diseases and should be absent in animal products. Rapid and accurate identification of pathogens in the supply chain is important for both quality assurance and tracking infectious agents within the chain. In this context, this study aimed to evaluate the equivalence of two rapid detection tests, as alternative methods to the conventional Salmonella detection method, as well as to verify the microbiological quality parameters of two commercially important fish species in the Amazon biome. The plate count of aerobic bacteria ranged from $7.76 \mathrm{x} 10^{4}$ to $8.71 \times 10^{7} \mathrm{CFU} . \mathrm{g}^{-1}$ for mesophiles and $1.70 \times 10^{6}$ to $4.27 \times 10^{8} \mathrm{CFU} . \mathrm{g}^{-1}$ for psychrotrophic whereas the maximum for this group of microorganisms in fresh fish is $10^{6} \mathrm{CFU} . \mathrm{g}^{-1}$. Regarding the Staphylococcus count, the two species presented variations between $1.35 \times 10^{4}$ to $1.51 \times 10^{5} \mathrm{CFU} . \mathrm{g}^{-1}$. This represents unsatisfactory conditions of handling, storage and conservation of fish species. The immunoenzymatic and molecular methods have been shown to be reliable, fast and effective in the detection of Salmonella and for its high index of agreement with the conventional detection method. We also emphasize the convenience of multiplex PCR application due to the high sensitivity, specificity, speed and accuracy of Salmonella detection.
\end{abstract}

Keywords: Brachyplatystoma filamentosum; Ilisha amazonica; mPCR; Tecra Salmonella.

Practical Application: Identify the presence of salmonella through fast methods and molecular identification techniques.

\section{Introduction}

Microbiological safety of fish is a concern of consumers, industries and regulatory agencies around the world nowadays. The rapid and accurate identification of pathogens in the supply chain is important both for quality assurance and for tracking infectious agents within the chain (Välimaa et al., 2015; Sebastião, et al., 2015; Buncic, et al., 2019). According to data from regulatory agencies and health inspection agencies worldwide Salmonella stands out among the pathogens, as the main bacterial agent, responsible for transmit diseases associated with food consumption nowadays (Centers for Disease Control and Prevention, 2016; European Food Safety Authority, 2018). In Europe, authorities point to Salmonella as the second most important agent in foodborne disease transmission, with over 91,857 cases of salmonellosis (European Food Safety Authority, 2018; Trimoulinard et al., 2017). In the United States, the incidence of Salmonella represents 15.89\% of the cases associated with diseases transmitted by food consumption (Centers for Disease Control and Prevention, 2016). In Brazil, Salmonella is responsible for more than $30 \%$ of foodborne diseases, according to the Brazilian Ministry of Health (Brasil, 2017).
Although Salmonella is not a biologically natural pathogen of fish, it can be introduced to the fish chain through improper handling and hygiene in processing or contact with contaminated water by discharging sewage effluent into fishing basins. Salmonella are facultative intracellular parasites that invade the mucous membrane with the human and animal intestinal tract being the main reservoir of this pathogen (Álvarez-Ordóñez et al., 2012; Ertas Onmaz et al., 2015; Nhung et al., 2018). The conventional method used for the detection of Salmonella in food is based on pre-enrichment in buffered peptone water (BPW) and enrichment in selective medium, followed by differential isolation and serological confirmation (Suo \& Wang, 2014; Lee, et al., 2015; $\mathrm{Li}$, et al., 2017). The main limitation of this method is that these tests usually require a minimum of 5 to 6 days. However, infection control increasingly depends on faster and more accurate tests for the diagnosis of this pathogen, especially for monitoring the production of animal products, food manufacturing and end products (Andrade et al., 2010; Frickmann, et al., 2013; Gokduman et al., 2016; Lobato \& O'Sullivan, 2018). In addition, there is a strong industrial demand to comply with legislation and

Received 06 Jan., 2020

Accepted 27 Jan., 2020

${ }^{1}$ Laboratório de Análise de Alimentos - LAANALI, Programa de Pós-graduação em Ciência e Tecnologia de Alimentos - PPGCTA, Universidade Federal do Pará - UFPA,

Campus Guamá, Belém, PA, Brasil

${ }^{2}$ Laboratório de Higiene e Qualidade de Alimentos, Programa de Pós-graduação em Saúde Animal na Amazônia, Universidade Federal do Pará - UFPA, Campus Castanhal, Belém, PA, Brasil

\# These authors contributed equally to this manuscript.

*Corresponding author: 1hmeller@ufpa.br 
the rapid release of food products to the market. Recent advances in technologies for the detection and identification of contaminated foodborne pathogens have provided faster, more sensitive and specific alternatives to conventional methods (Paula, et al. 2002; Kawasaki, et al., 2009; Koo, et al., 2016; Suo, et al., 2017) These assays are generally referred as "fast" or alternative methods, terms commonly used to describe a variety of assays including miniaturized biochemical kits, immunoassays, DNA/ RNA-based assays, and combinations with cultural methods (Lofstrom et al., 2010; Almeida et al., 2013; Kim, et al., 2017). Molecular testing uses a specific sequence of bacterial nucleic acids as a target for pathogen detection and this is the category of alternative methods that most improved in recent years (Valderrama et al., 2016; Hu, et al., 2018; Bundidamorn, et al., 2018). The PCR assay, Polymerase Chain Reaction, is the molecular test that has also been widely used to detect Salmonella in food. It is a highly sensitive technique based on enzymatic amplification of specific segments of DNA in vitro, which enables to obtain thousands of copies from a single nucleic acid sequence, within two or three hours (Shabarinath et al., 2007; Singh et al., 2019).

Another rapid assay that has been extensively studied in the analysis for pathogen detection is multiplex PCR. This technique involves more than one pair of oligonucleotides and allows, among other applications, to perform a single reaction to detect various types of microorganism, their serotypes or different genes of the same microorganism (Malorny et al., 2009; Wang, et al., 2015; Chin et al., 2017).

In this context, the objective of this study was to evaluate the equivalence of two rapid detection tests as alternative methods to the conventional method of bacteriological detection of Salmonella in two fish species with commercial importance and large occurrence in the Amazon biome and associated with this verify the parameters of microbiological qualities of the two species of fish.

\section{Materials and methods}

\subsection{Samples and procedure for isolation and identification}

The fish samples included in this study were Brachyplatystoma filamentosum and Ilisha amazonica species. These two species are of large occurrence in the Amazon biome and commercially important for their high consumption. The total of 10 collections of fish samples were performed in the period from January to June 2018, at the main North fish landing port in Brazil (Ver-o-Peso market, $01^{\circ} 27^{\prime} 21^{\prime \prime} \mathrm{S}$ and $48^{\circ} 30^{\prime} 14^{\prime \prime} \mathrm{W}$ ). Four batches of fish (without evisceration) of each species, which constituted separate samples, were placed in sterile polyethylene bags, stored under refrigeration $\left(5^{\circ} \mathrm{C}\right)$ and transported to the laboratory of the Federal University of Pará-UFPA, where the analyzes were initiated immediately upon arrival.

\subsection{Sample preparation}

For the preparation of the material to be submitted to microbiological analysis and isolation of Salmonella from fish samples, the protocol described in the Compendium of Methods for Microbiological Examination of Foods (American
Public Health Association, 2001) was followed. Briefly, $25 \mathrm{~g}$ of the samples were homogenized with $225 \mathrm{~mL}$ buffered peptone water (Oxoid CM509) using a stomacher mixer (Logen Scientifc, LS1901n, ALPAX) at $2000 \mathrm{rpm}$ for $2 \mathrm{~min}$. From the initial suspension, decimal dilutions were prepared by transferring $1 \mathrm{~mL}$ from the previous dilution to $9 \mathrm{~mL}$ of buffered peptone water and so on until reaching the desired dilution. From the decimal dilutions obtained, analyzes of total and thermotolerant coliforms, Staphylococcus aureus and total and psychrotrophic aerobic bacteria count were performed as follows.

\subsection{Microbiological analysis}

The presumptive coliforms test was performed using the CC Petrifilm ${ }^{\mathrm{TM}}$ commercial kit (3M Company, St. Paul, MN, USA), where $1 \mathrm{~mL}$ of the dilution, obtained according to item 2.2, was inoculated into the kit plates, according to manufacturer's instructions. The plates were incubated at $35^{\circ} \mathrm{C}$ for $48 \mathrm{~h}$, and the result was expressed in MPN of total coliforms per gram of sample. For Thermotolerant Coliforms, $1 \mathrm{~mL}$ aliquots of three dilutions of the sample obtained according to item 2.2 were inoculated into a series of 3 tubes containing $10 \mathrm{~mL}$ of Tryptose Lauryl Sulfate Broth - LST (ACUMEDIA 7142) and incubated at $35^{\circ} \mathrm{C}$. After $48 \mathrm{~h}, 1 \mathrm{~mL}$ aliquots of each positive tube of LST were transferred to tubes containing $10 \mathrm{~mL}$ of Escherichia coli broth - EC (Acumedia 7206) and incubated at $45^{\circ} \mathrm{C}$ for $24 \mathrm{~h}$ in a water bath, and the result was expressed in MPN of thermotolerant coliforms per gram of sample. For quantification of Staphylococcus aureus, the commercial Petrifilm $^{\mathrm{TM}}$ Staph express Cout Plate kit (3M Company, St. Paul, MN, USA) was used, where $1 \mathrm{~mL}$ of the sample dilution obtained according to item 2.2 was inoculated into kit plates, and the plates were incubated at $36^{\circ} \mathrm{C}$ for $24 \mathrm{~h}$ according to the manufacturer's instructions. After the plates incubation period, typical Staphylococcus colonies were counted and the result expressed in CFU.g-1 ${ }^{-1}$ In the mesophilic and psychrotrophic aerobic bacterial count assays, the "pour plate" technique with standard agar (PCA) was performed. The plates were incubated at $35^{\circ} \mathrm{C}$ for $48 \mathrm{~h}$ (mesophilic) and $7^{\circ} \mathrm{C}$ for 10 days (psychrotrophic). The result of the count was expressed in CFU.g-1.

\subsection{Salmonella spp. detection}

In Salmonella detection were applied three protocols, which are described briefly as follows:

\section{Traditional method}

By the traditional method, the procedures were performed according to the methodology described in ISO 6579 (American Public Health Association, 2001), where aliquots of the sample prepared according to item 2.2 were incubated at $37^{\circ} \mathrm{C}$ for $24 \mathrm{~h}$. From the BPW pre-enriched culture, $0.1 \mathrm{~mL}$ was transferred to tubes containing $10 \mathrm{~mL}$ of Rappaport-Vassiliadis Soya (RVS) Broth. RVS broth was incubated at $42{ }^{\circ} \mathrm{C}$ for $24 \mathrm{~h}$. From the selective enrichment broth, streaks were performed on plates with Salmonella Shigella (SS) Agar and Xylose-Lysine-Deoxycholate (XLD) Agar, and incubated at $35^{\circ} \mathrm{C}$ for $24 \mathrm{~h}$. Plates showing typical colony growth were collected for biochemical and serological 
identification to confirm the presence of Salmonella, according to the methodology described in the Compendium of Methods for Microbiological Examination of Foods (American Public Health Association, 2001).

\section{Fast detection immunoenzymatic method}

In this type of rapid detection assay, the investigated pathogens, if present in the test product, are captured by specific antibodies adsorbed on the surface of a solid matrix. In this study, the immunoenzymatic assay was performed using the Tecra Salmonella kit (3M Company, St. Paul, MN, USA), which briefly, $1 \mathrm{~mL}$ of pre-enriched mixture in RVS broth was transferred to tubes containing $10 \mathrm{~mL}$ of $\mathrm{M}$-broth and incubated at $35^{\circ} \mathrm{C}$ for $8 \mathrm{~h}$. Subsequently, a $1 \mathrm{~mL}$ aliquot of M-broth was heated in a water bath $\left(\sim 100^{\circ} \mathrm{C}\right)$ for $15 \mathrm{~min}$. After cooling, $200 \mu \mathrm{L}$ aliquots of M-broth were placed in kit's individual wells following the manufacturer's procedures protocol for detection of salmonella in the product. Samples showing positive detection for Salmonella were submitted to biochemical and serological identification to confirm the presence of Salmonella according to the protocol described in the Compendium of Methods for Microbiological Examination of Foods (American Public Health Association, 2001).

\section{Rapid detection MPCR molecular method}

The multiplex Polymerase Chain Reaction (mPCR) assay is one of the most widely used molecular tests for Salmonella detection and its fundamental feature is the enzymatic amplification of specific segments of DNA in vitro, which enables to obtain thousands of copies from a single sequence of nucleic acid in a short time. In preparing samples for the mPCR assay, DNA extraction was performed using the protocol described by Darwish et al. (2009), with some modifications. A $2 \mathrm{~mL}$ aliquot of the sample prepared according to item 2.2 and reactivated in Brain Heart Infusion (BHI) broth at $37^{\circ} \mathrm{C}$ for $18 \mathrm{~h}$ was transferred to Eppendorf and centrifuged at 13,200.0 $\times \mathrm{g}$ for $5 \mathrm{~min}$. The supernatant was discarded and the pellet formed resuspended in $600 \mu \mathrm{L}$ of Lysis buffer T1 (Kasvi, Brazil) and $10 \mu \mathrm{L}$ of proteinase $\mathrm{K}(20 \mathrm{mg} / \mathrm{mL})$ were then added to the suspension. After incubation in a $56^{\circ} \mathrm{C}$ water bath for $6 \mathrm{~h}$ the samples were centrifuged at $10,000 \times \mathrm{g}$ for $10 \mathrm{~min}$. To optimize the separation and precipitation of protein was added $700 \mu \mathrm{L}$ of phenol-chloroform (1:1), cooled to $5{ }^{\circ} \mathrm{C}$ for $5 \mathrm{~min}$, and a further centrifugation was performed at $14,000 \times \mathrm{g}$ for $20 \mathrm{~min}$. An aliquot of $400 \mu \mathrm{L}$ of the supernatant was transferred to a new flask containing $600 \mu \mathrm{L}$ of isopropanol, then centrifuged at $14,000 \times \mathrm{g}$ for $1 \mathrm{~min}$. The supernatant was completely discarded and $600 \mu \mathrm{L}$ of $70 \%$ ethanol was added and centrifuged at $14,000 \times \mathrm{g}$ for $1 \mathrm{~min}$. The supernatant was discarded again and the flasks were oven dried at $37^{\circ} \mathrm{C}$ for $30 \mathrm{~min}$. DNA samples were hydrated with $100 \mu \mathrm{L}$ TE buffer solution (10 mM Tris- $\mathrm{HCl}$, $1 \mathrm{mM}$ EDTA) and stored at $-18^{\circ} \mathrm{C}$ until use in mPCR analysis. For the target gene, the following primers were used: prime Forward: 5' TATCGCCACGTTCGGGCAA 3' and Reverse: 5' TCGCACCGTCAAAGGAACC 3' amplifying 275bp sequences, prime Forward: 5' CGGTGTTGCCCAGGTTGGTAAT 3' and Reverse: 5' ACTGGTAAAGATGGCT 3', which amplify 620bp sequences and prime Forward: 5’ AGATTGGGCACTACACGTGT ' 3 and Reverse: 5' TGTACTCCACCAGGTAATTG 3', which amplify 535bp sequences. These primes were previously configured based on studies described in the literature (Wang et al., 1997; Aabo et al., 1993; Soumet et al., 1999). Primers were synthesized by Ludwing Biotec ${ }^{\oplus}$ and prepared according to the manufacturer's instructions and diluted in sterile ultrapure water and TE $8.0 \mathrm{pH}$ buffer to $100 \mathrm{pmol} \mu \mathrm{L}^{-1}$. Amplifications were performed using a thermal cycler (Applied Biosystems VERITI ${ }^{\circ} 96$ ) programmed for initial denaturation at $94^{\circ} \mathrm{C}$ for $30 \mathrm{~s}$, followed by $35 \mathrm{cycles}$ with denaturation for $30 \mathrm{~s}$, annealing for $1 \mathrm{~min}$ at $55^{\circ} \mathrm{C}$ and extension for $30 \mathrm{~s}$ at $72^{\circ} \mathrm{C}$, followed by a final extension at $72^{\circ} \mathrm{C}$ for $7 \mathrm{~min}$. Finally, the samples were kept at $4{ }^{\circ} \mathrm{C}$. The PCR products were separated by $1.5 \%$ agarose gel electrophoresis, stained with Safer dye (KASVI $)$ and visualized by transillumination (Gel Documentation System, Gel Doc ${ }^{\mathrm{Tm}} \mathrm{XR}+$, Bio-Rad ${ }^{\circ}$ ) with the aid of Image Lab Software Version 5.2.1.

\section{DNA sequencing}

The sequencing was conducted as described by Malorny et al. (2009). Briefly, the sequencing was performed using the $A B$ 3500 Genetic Analyzer automated sequencer armed with $50 \mathrm{~cm}$ capillaries and POP-7 polymer (Applied Biosystems). DNA templates, previously selected, were labeled using $2.5 \mathrm{pmol}$. The resulting sequences after editing with Chromas Lite ${ }^{\varpi}$ and Bioedit software were then submitted to Genbank (National Center for Biotechnology Information, 2016) where they could be compared by similarity to the other sequences already deposited, using BLAST online software. This analysis procedure provided the gene fragment identification as belonging to a particular genus or species, considering the similarity percentage above $98 \%$.

\subsection{Statistical analysis}

Analyses were performed in triplicate $(n=3)$. Tests of the significance of the results were performed using an one-way analysis of variance (ANOVA) using the Microsoft Office Excel for Windows 7.0.

\section{Results and discussion}

\subsection{Microbiological quality}

The microbiological evaluation results of in natura Brachyplatystoma filamentosum and Ilisha amazonica species, related to hygiene indicator microorganisms or processing, fecal contamination, handling and enteric waterborne pathogens are shown in Table 1. The aerobic bacteria plate count, used as indicator of hygiene and temperature control during processing for Brachyplatystoma filamentosum species, showed variations between $8 \times 10^{4}$ to $1.1 \times 10^{6} \mathrm{CFU}^{-1} \mathrm{~g}^{1}$ for mesophiles and $7.4 \times 10^{7}$ to $1.3 \times 10^{7} \mathrm{CFU} . \mathrm{g}^{-1}$ for psychrotrophic. It was verified by one-way ANOVA, that the statistical analysis globally indicated, for the lots of Brachyplatystoma filamentosum samples throughout the six months of collection, the existence of significant fact $(\mathrm{p}<0.05)$, linked to the count of mesophilic and psychrotrophic aerobic bacteria. It is also observed (Table 1) that in the group of mesophilic bacteria, from the total collections performed 
Table 1. Microbiological quality of Brachyplatystoma filamentosum and Ilisha amazonica species.

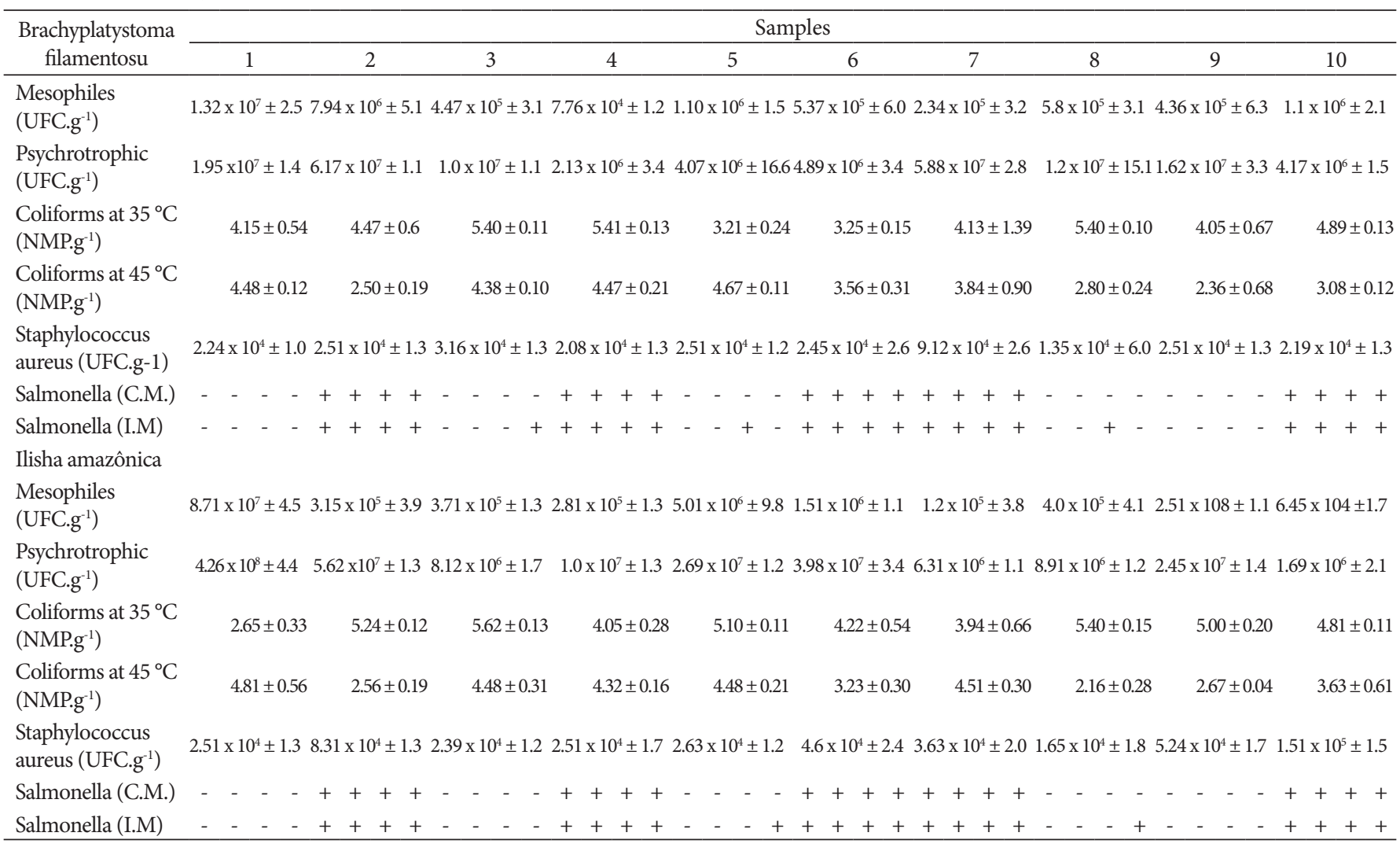

C.M. (Conventional Method); I.M. (Immunoenzymatic Method); Positive result (+); Negative result (-).

in this study for Brachyplatystoma filamentosum species, $40 \%$ exceeded the maximum limit of $10^{6} \mathrm{CFU} \cdot \mathrm{g}^{-1}$ established by the International Commission on Microbiological Specifications for Foods standards (International Commission on Microbiological Specifications for Foods, 2002). However, regarding the group of psychrotrophic bacteria, $80 \%$ of the samples collected for Brachyplatystoma filamentosum species exceeded the limit of $10^{6} \mathrm{CFU} . \mathrm{g}^{-1}$. The high count of these bacteria in fish represents unsatisfactory storage and conservation conditions of the product. Thus, the proper handling and storage of Brachyplatystoma filamentosum becomes essential, as psychrotrophic bacteria are endowed with proteolytic and lipolytic characteristics that may continue their multiplication process, which may affect the durability of fish even stored in favorable temperatures. Regarding the Ilisha amazonica species, the count of mesophilic and psychrotrophic aerobic bacteria showed variations between $1.0 \times 10^{6}$ to $7.8 \times 10^{5} \mathrm{CFU} . \mathrm{g}^{-1}$ and $1.10 \times 10^{7}$ to $8.9 \times 10^{6} \mathrm{CFU}^{-1}{ }^{-1}$ respectively. Statistical analysis also showed that the aerobic bacteria counts showed significant variations $(\mathrm{p}<0.05)$ over the six months of collection. It was also verified (Table 1) that the species Ilisha amazonica presented the same nonconformities as Brachyplatystoma filamentosum, since $60 \%$ of the samples collected exceeded the limit of $10^{6} \mathrm{CFU} \cdot \mathrm{g}^{-1}$ for the group of psychrotrophic bacteria. The results related to the total and thermotolerant coliforms group of Brachyplatystoma filamentosum showed variations between $1.7 \times 10^{3}$ to $8.5 \times 10^{4} \mathrm{MPN}^{-1}$ and $1.2 \times 10^{3}$ to $3.0 \times 10^{4} \mathrm{MPN} . \mathrm{g}^{-1}$ respectively. While Ilisha amazonica presented total coliforms between $1.0 \times 10^{5}$ to $8.0 \times 10^{4} \mathrm{MPN} . \mathrm{g}^{-1}$ and thermotolerant coliform variations between $1.0 \times 10^{5}$ to $1.3 \times 10^{4} \mathrm{MPN} \mathrm{g}^{-1}$. Total and thermotolerant coliform counts in fresh fish can be considered as indicator of quality, because the presence of this group is commonly associated with pathogenic bacteria, being considered as risk to consumer health. The International Commission on Microbiological Specifications for Foods (2002) establishes for this group of microorganisms the maximum limit of $10^{3} \mathrm{MPN.g}^{-1}$ in fresh fish. In the present study, the bacteriological results (Table 1) related to the group of total and thermotolerant coliforms, for the two fish species evaluated, evidence inadequate hygiene and sanitation practices, according to the standards required for processing this food. Statistical analysis also indicates that, globally, for both Brachyplatystoma filamentosum and Ilisha amazonica species the bacteriological counts related to the total and thermotolerant coliforms group showed significant variations $(\mathrm{p}<0.05)$ over the collection period. Regarding the Staphylococcus count, Brachyplatystoma filamentosum showed variations between $>1.0 \times 10^{1}$ to $2.5 \times 10^{4} \mathrm{CFU}_{\mathrm{g}}{ }^{-1}$, while the Ilisha amazonica species ranged from $>1.0 \times 10^{1}$ to $5.6 \times 10^{4} \mathrm{CFU}^{-1}{ }^{-1}$. The International Commission on Microbiological Specifications for Foods (2002) establishes for this group of microorganisms the maximum limit of $10^{3} \mathrm{CFU} . \mathrm{g}^{-1}$ in fresh fish. In the present study $40 \%$ of the samples collected related to the two fish species evaluated exceeded the maximum limit established. Although Staphylococcus is not part of neither evaluated fish species microbiota, the presence of this group of microorganisms in the samples is likely to result from cross-contamination, as these bacteria are common to human 
skin, nasal cavity and oral cavity, being used as indicators of hygienic character deficiencies in the food obtaining process and in the operations of manipulation. Statistical analysis also indicates that globally, for both Brachyplatystoma filamentosum and Ilisha amazonica species, bacteriological counts related to Staphylococcus showed no significant variations ( $p>0.05)$ over the collection period.

\subsection{Salmonella spp. detection}

The results in Table 1 show the incidence of Salmonella in various samples for both Brachyplatystoma filamentosum and Ilisha amazonica species detected by conventional method and confirmed by the immunoenzymatic method performed with Tecra commercial kit. Considering the positive confirmed results and negative results together, it was found that of the 40 samples analyzed by the conventional method over the 10 collections, $30 \%$ of the samples of Brachyplatystoma filamentosum presented Salmonella contamination. For Ilisha amazonica, the contamination was $50 \%$ of the collected samples. The total number of Salmonella positive samples was 8 . In this study, the agreement rate between the conventional Salmonella detection method and the detection by the immunoenzymatic method performed with the commercial Tecra kit was $92.5 \%$ for samples of specie Brachyplatystoma filamentosum and $95.0 \%$ for samples of specie Ilisha amazonica (Table 1). Taking this result as a reference point, we emphasize the convenience of applying this method for Salmonella detection due to its simplicity of execution and rapid availability of the screening result, so the immunoenzymatic method applicability performed by the Tecra commercial kit may satisfy the need for rapid diagnosis of the industry and regulatory agencies with excellent accuracy.

For the genetic identification by molecular method of serotypes isolated from Brachyplatystoma filamentosum and Ilisha amazonica species using the conventional Salmonella detection method, the multiplex PCR method was applied. This method makes possible to confirm the genus and to detect the species simultaneously by combining several specific primers for target genes, as two or more DNA fragments are amplified in the same reaction. Figure 1 shows the result of multiplex PCR agarose gel where it is possible to observe two bands corresponding to fragments 239, 527 and $578 \mathrm{bp}$, confirming positive contamination of fish by Salmonella and pointing out the existence of 2 different serotypes. After the subsequent alignment of the previously selected primers and BLAST evaluation with the GenBank genomic database, the result achieved in this test was satisfactory to obtain a multiplex PCR capable of detecting Salmonella spp. and differentiate between Salmonella typhimurium (Figure 1A) and Salmonella enteritidis (Figure 1B) subspecies. The amplification of the target genes occurred as expected: pure culture Salmonella samples showed bands corresponding to the $239 \mathrm{bp}$ fragment with 98\% of identification and coverage for the CP018219.1 gene available on the GenBanck data platform, and Salmonella typhimurium presented the bands corresponding to the $578 \mathrm{bp}$ fragment with $98 \%$ of identification and $99 \%$ of coverage for the CP024619.1 gene available on the GenBanck data platform. Salmonella enteritidis exhibited bands corresponding to the 527 bp fragment showing $98 \%$ of identification and coverage for the CP032851.1 gene available on the GenBanck data platform. In the Brachyplatystoma filamentosum species the serotype identified was only Salmonella Enteritidis whereas in the species Ilisha amazonica both Salmonella Enteritidis and Salmonella typhimurium serotypes were detected. Taking this result as a reference point, we emphasize the convenience of applying multiplex PCR developed in this study, demonstrated by its high sensitivity, specificity and accuracy, besides showing strong agreement with the reference method for the detection of Salmonella. It is important to highlight that Salmonella Enteritidis and Salmonella typhimurium are common serotypes

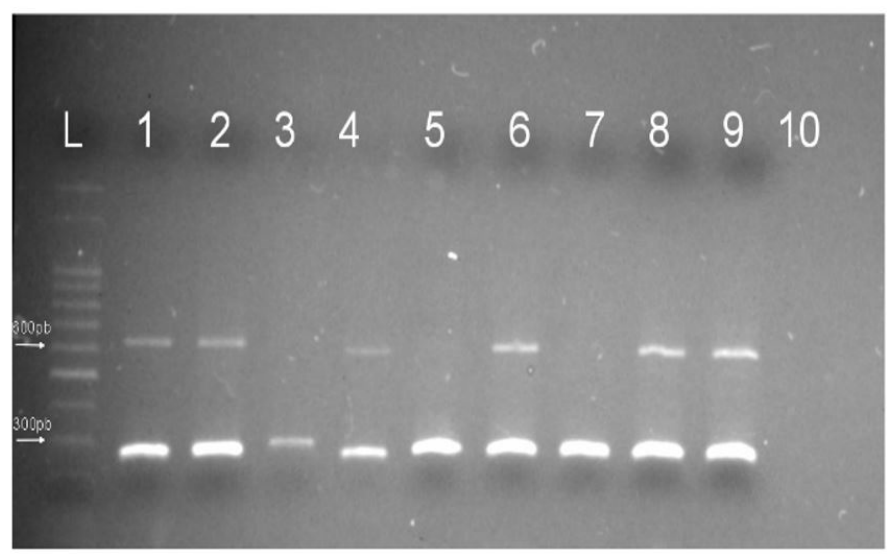

(A)

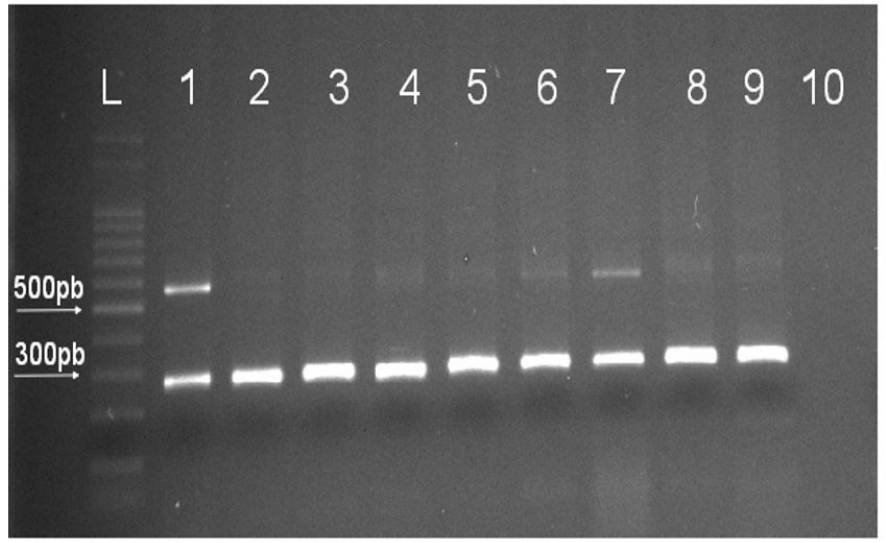

(B)

Figure 1. (A) 1.5\% agarose gel electrophoresis demonstrating the presence of DNA fragment genus Salmonella spp and serovar typhimurium. Where, L: molecular weight marker (100bp), 1: positive control of Salmonella spp., And typhimurium, 2 to 9: strains isolated from fish samples, 10: negative control; (B) 1.5\% agarose gel electrophoresis demonstrating the presence of Salmonella spp DNA fragment and serovar enteretides. Where, L: molecular weight marker (100bp), 1: positive control of Salmonella spp., And enteretides, 2 to 9: strains isolated from fish samples, 10: negative control. 
in contaminated estuaries and coastal waters, and can be found in fish and shellfish from tropical waters having multiresistant strains for disinfectants. In addition, they have a reasonable ability to form biofilm providing them a certain factor of permanence in the environment, which is crucial in the contamination of equipment and accessories used in fish processing.

\section{Conclusion}

The results obtained from the microbiological evaluation of Brachyplatystoma filamentosum and Ilisha amazonica in natura species show that some hygienic conditions along the fishing chain were not adequate due to the high count values of microorganisms not belonging to the normal flora of these two fish species. Therefore, it is recommended to apply improved hygienic practices in fish handling and processing until it arrives at the selling point in order to provide a product with quality and health safety. The immunoenzymatic and molecular methods have been shown to be reliable, fast and effective in the detection of Salmonella and its high level of agreement with the conventional method of detection of this pathogen. The study also reveals that the multiplex PCR protocol applied was able to detect Salmonella Enteritidis and Salmonella typhimurium serotypes simultaneously and could serve as an alternative in the quality control laboratory routine of fish industry and regulatory agencies in the diagnosis of foodborne pathogenic bacteria such as Salmonella.

\section{Acknowledgements}

The authors thank PROPESP/UFPA (Provost's Office for Research and Graduate Studies of the Federal University of Pará), CNPq (National Research and Development Council, processes, 309876/2016-8, 308396/2018-9 and 313453/20195 ), and CAPES (Coordination for the Improvement of Higher Education Personnel).

\section{References}

Aabo, S., Rasmussen, O. F., Roseen, L., Sørensen, P. D., \& Olsen, J. E. (1993). Salmonella identification by the polymerase chain reaction. Molecular and Cellular Probes, 7(7), 171-178. http://dx.doi.org/10.1006/ mcpr.1993.1026. PMid:8366864.

Almeida, C., Cerqueira, L., Azevedo, N. F., \& Vieira, M. J. (2013). Detection of Salmonella enterica serovar enteritidis using real time PCR, immunocapture assay, PNA FISH and standard culture methods in different types of food samples. International Journal of Food Microbiology, 161(1), 16-22. http://dx.doi.org/10.1016/j. ijfoodmicro.2012.11.014. PMid:23246608.

Álvarez-Ordóñez, A., Prieto, M., Bernardo, A., Hill, C., \& López, M. (2012). The acid tolerance response of Salmonella spp.: an adaptive strategy to survive in stressful environments prevailing in foods and the host. Food Research International, 45(2), 482-492. http://dx.doi. org/10.1016/j.foodres.2011.04.002.

American Public Health Association - APHA. (2001). Compendium of methods for the microbiological examination of foods. Washington: APHA.

Andrade, R. B., Gemelli, T., Dall Onder, L. P., Cristina, K., Brito, T., Barboza, A. A. L., \& Brito, B. G. (2010). Métodos diagnósticos para os patógenos alimentares: Campylobacter sp., Salmonella sp. e Listeria monocytogenes. Arquivos do Instituto Biológico, 74(4), 741-750.

Brasil. Ministério da Saúde. Secretaria de Vigilância em Saúde. Coordenação Geral de Doenças Transmissíveis. Unidade Técnica de Doenças de Veiculação Hídrica e Alimentar. (2017). Doenças transmitidas por alimentos (Boletim Eletrônico Epidemiológico). Brasília: Ministério da Saúde.

Buncic, S., Alban, L., \& Blagojevic, B. (2019). From traditional meat inspection to development of meat safety assurance programs in pig abattoirs -The European situation. Food Control, 106, 1-12. http:// dx.doi.org/10.1016/j.foodcont.2019.06.031.

Bundidamorn, D., Supawasit, W., \& Trevanich, S. (2018). A new singletube platform of melting temperature curve analysis based on multiplex real-time PCR using EvaGreen for simultaneous screening detection of Shiga toxin-producing Escherichia coli, Salmonella spp. and Listeria monocytogenes in food. Food Control, 94, 195-204. http://dx.doi.org/10.1016/j.foodcont.2018.07.001.

Centers for Disease Control and Prevention - CDC. (2016). Salmonella. USA: CDC. Retrieved from https://www.cdc.gov/salmonella

Chin, W. H., Sun, Y., Høgberg, J., Quyen, T. L., Engelsmann, P., Wolff, A., \& Bang, D. D. (2017). Direct PCReA rapid method for multiplexed detection of diferente serotypes of Salmonella in enriched pork meat samples. Molecular and Cellular Probes, 32, 24-32. http://dx.doi. org/10.1016/j.mcp.2016.11.004. PMid:27871797.

Darwish, S. F., Allam, H. A., \& Amin, A. S. (2009). Evaluation of PCR assay for detection of cow's milk in water buffalo's milk. World Applied Sciences Journal, 7(4), 461-467.

Ertas Onmaz, N., Abay, S., Karadal, F., Hizlisoy, H., Telli, N., \& Al, S. (2015). Occurence and antimicrobial resistance of Staphylococcus aureus and Salmonella spp. in retail fish samples in Turkey. Marine Pollution Bulletin, 90(1-2), 242-246. http://dx.doi.org/10.1016/j. marpolbul.2014.10.046. PMid:25467866.

European Food Safety Authority - EFSA. (2018). The European Union One Health 2018 Zoonoses Report. Information about salmonella. Parma: EFSA. Retrieved from https://www.efsa.europa.eu/en/ efsajournal/pub/5926

Frickmann, H., Hanle, A., Essig, A., Dekker, D., Boahen, K., Acquah, S., Sarpong, N., Adu-Sarkodie, Y., Schwarz, N. G., May, J., Marks, J., Hagen, R. M., \& Poppert, S. (2013). Fluorescence in situ hybridization (FISH) for rapid identification of Salmonella spp.from agar and blood culture broth-Na option for the tropics. International Journal of Medical Microbiology, 303(5), 277-284. http://dx.doi.org/10.1016/j. ijmm.2013.04.001. PMid:23642903.

Gokduman, K., Avsaroglu, M. D., Cakiris, A., Ustek, D., \& Gurakan, G. C. (2016). Recombinant plasmid-based quantitative Real-Time PCR analysis of Salmonella entericaserotypes and its application to milk samples. Journal of Microbiological Methods, 122, 50-58. http://dx.doi.org/10.1016/j.mimet.2016.01.008. PMid:26820062.

Hu, L., Deng, X., Brown, E., Hammack, T. S., Ma, L. M., \& Zhang, G. (2018). Evaluation of Roka Atlas Salmonella method for the detection of Salmonella in egg products in comparison with culture method, real-time PCR and isothermal amplification assays. Food Control, 94, 123-131. http://dx.doi.org/10.1016/j. foodcont.2018.06.039.

International Commission on Microbiological Specifications for Foods - ICMSF. (2002). Microorganisms in Foods. Microbiological testing in food safety management. New York: Kluwer Academic/ Plenum Publishers.

Kawasaki, S., Fratamico, P. M., Horikoshi, N., Okada, Y., Takeshita, K., Sameshima, T., \& Kawamoto, S. (2009). Evaluation of a multiplex PCR system for simultaneous detection of Salmonella spp., Listeria 
monocytogenes, and Escherichia coli O157:H7 in foods and in food subjected to freezing. Foodborne Pathogens and Disease, 6(1), 81-89. http://dx.doi.org/10.1089/fpd.2008.0153. PMid:18991547.

Kim, S. A., Park, S. H., Lee, S. I., \& Ricke, S. C. (2017). Rapid and simple method by combining FTATM card DNA extraction with two set multiplex PCR for simultaneous detection of non-O157 Shiga toxin-producing Escherichia coli strains and virulence genes in food samples. Letters in Applied Microbiology, 65(6), 482-488. http://dx.doi.org/10.1111/lam.12805. PMid:28960364.

Koo, E. J., Kim, D., \& Oh, S. W. (2016). Comparison of DNA isolation methods for detection of food borne pathogens by real-time PCR from foods. Korean Journal of Food Science Technology, 48(4), 335340. http://dx.doi.org/10.9721/KJFST.2016.48.4.335.

Lee, K. M., Runyon, M., Herrman, T. J., Phillips, R., \& Hsieh, J. (2015). Review of Salmonella detection and identification methods: aspects of rapid emergency response and food safety. Food Control, 47, 264276. http://dx.doi.org/10.1016/j.foodcont.2014.07.011.

Li, F., Li, F., Chen, B., Zhou, B., Yu, P., Yu, S., Lai, W., \& Xu, H. (2017). Sextuplex PCR combined with immunomagnetic separation and PMA treatment for rapid detection and specific identification of viable Salmonella spp., Salmonella enterica serovars Paratyphi B, Salmonella Typhimurium, and Salmonella Enteritidis in raw meat. Food Control, 73(Pt B), 587-594. http://dx.doi.org/10.1016/j. foodcont.2016.09.009.

Lobato, I. M., \& O’Sullivan, C. K. (2018). Recombinase polymerase amplification: basics, applications andrecent advances. Trends in Analytical Chemistry, 98, 19-35. http://dx.doi.org/10.1016/j. trac.2017.10.015. PMid:32287544.

Lofstrom, C., Hansen, F., \& Hoorfar, J. (2010). Validation of a 20-h real-time PCR method for screening of Salmonella in poultry faecal samples veterinary. Microbiology, 144(3-4), 511-514.

Malorny, B., Huehn, S., Dieckmann, R., Krãmer, N., \& Helmuth, R. (2009). Polymerase chain reaction for the rapid detection and serovar identification of Salmonella in food and feeding stuff. Food Analytical Methods, 2(2), 81-95. http://dx.doi.org/10.1007/s12161-008-9057-9.

National Center for Biotechnology Information - NCBI. (2016). Rockville: NCBI. Retrieved from www.ncbi.nlm.nih.gov

Nhung, N. T., Van, N. T. B., Cuong, N. V., Duong, T. T. Q., Nhat, T. T., Hang, T. T. T., Nhi, N. T. H., Kiet, B. T., Hien, V. B., Ngoc, P. T., Campbell, J., Thwaites, G., \& Carrique-Mas, J. (2018). Antimicrobial residues and resistance against critically importantanti-microbials in non-typhoidal Salmonella from meat sold at wet markets and supermarkets in Vietnam. International Journal of Food Microbiology, 266, 301-309. http://dx.doi.org/10.1016/j.ijfoodmicro.2017.12.015. PMid:29275223.

Paula, A. M., Gelli, D. S., Landgraf, M., Destro, M. T., \& Franco, B. D. (2002). Detection of Salmonella in foods using Tecra Salmonella VIA and Tecra Salmonella UNIQUE Rapid Immunoassays and a Cultural Procedure. Journal of Food Protection, 65(3), 552-555. http://dx.doi.org/10.4315/0362-028X-65.3.552. PMid:11899056.
Sebastião, F. A., Furlan, L. R., Hashimoto, D. T., \& Pilarski, F. (2015). Identification of bacterial fish pathogens in Brazil by direct colony PCR and 16S rRNA gene sequencing. Advances in Microbiology, 05(5), 409-424. http://dx.doi.org/10.4236/aim.2015.56042.

Shabarinath, S., Sanath Kumar, H., Khushiramani, R., Karunasagar, I., \& Karunasagar, I. (2007). Detection and characterization of Salmonella associated with tropical seafood. International Journal of Food Microbiology, 114(2), 227-233. http://dx.doi.org/10.1016/j. ijfoodmicro.2006.09.012. PMid:17141346.

Singh, P., Liu, Y., Bosilevac, J. B., \& Mustapha, A. (2019). Detection of Shiga toxin-producing Escherichia coli, $\mathrm{stx}_{1}, \mathrm{stx}_{2}$ and Salmonella by two high resolution melt curve multiplex real-time PCR. Food Control, 96, 251-259. http://dx.doi.org/10.1016/j.foodcont.2018.09.024.

Suo, B., \& Wang, Y. (2014). Evaluation of a multiplex selective enrichment broth SEL for simultaneous detection of injured Salmonella, Escherichia coli O157:H7 and Listeria monocytogenes. Brazilian Journal of Microbiology, 44(3), 737-742. http://dx.doi.org/10.1590/ S1517-83822013000300011. PMid:24516441.

Suo, Y., Gao, S., Xie, Y., Liu, Y., Qu, Y., Lin, T., \& Zhou, C. (2017). A multipathogen selective enrichment broth for simultaneous growth of Salmonella enteria, Escherichia coli O157:H7, and Shigella flexneri. Journal of Food Safety, 38(1), 1-9. https://doi.org/10.1111/jfs.12388.

Soumet, C., Ermel, G., Rose, V., Rose, N., Drouin, P., Salvat, G., \& Colin, P. (1999). Identification by a multiplex PCR-based assay of Salmonella typhimurium and Salmonella enteritidis strains from environmental swabs of poultry houses. Letters in Applied Microbiology, 29(1), 1-6. http://dx.doi.org/10.1046/j.1365-2672.1999.00559.x. PMid:10432625.

Trimoulinard, A., Beral, M., Henry, I., Atiana, L., Porphyre, V., Tessier, C., Leclercq, A., \& Cardinale, E. (2017). Contamination by Salmonella spp., Campylobacter spp. and Listeria spp. of most popular chickenand pork-sausages sold in Reunion Island. International Journal of Food Microbiology, 250, 68-74. http://dx.doi.org/10.1016/j. ijfoodmicro.2017.03.017. PMid:28371717.

Valderrama, W. B., Dudley, G. E., Doores, S., \& Cutter, N. C. (2016). Commercially available rapid methods for detection of selected food-borne pathogens. Critical Reviews in Food Science and Nutrition, 56(9), 1519-1531. http://dx.doi.org/10.1080/10408398.2013.77556 7. PMid:25749054.

Välimaa, A.-L., Tilsala-Timisjärvi, A., \& Virtanen, E. (2015). Rapid detection and identification methods for Listeria monocytogenesin the food chaine. Food Control, 55, 103-114. http://dx.doi.org/10.1016/j. foodcont.2015.02.037.

Wang, L., Ye, C., Xu, H., Aguilar, Z. P., Xiong, Y., Lai, W., \& Wei, H. (2015). Development of an SD-PMA-mPCR assay with internal amplification control for rapid and sensitive detection of viable Salmonella spp., Shigella spp. and Staphylococcus aureus in food products. Food Control, 57(7), 314-320. http://dx.doi.org/10.1016/j. foodcont.2015.04.016.

Wang, R. F., Cao, W. W., \& Cerniglia, C. E. (1997). A universal protocol for PCR detection of 13 species of foodborne pathogens in foods. Journal of Applied Microbiolgy, 83, 727-736. 